\title{
У Asiakaslähtöisyys lapsi- ja perhepalveluiden moniammatillisessa verkostoyhteistyössä vanhempien kokemana
}

Tutkimuksen tarkoituksena oli kuvailla vanhempien kokemuksia moniammatillisesta verkostoyhteistyöstä asiakaslähtöisyyden näkökulmasta lapsi- ja perhepalveluissa. Tutkimuksen tavoitteena oli tuottaa tietoa asiakaslähtöisyyden toteutumisesta lapsi- ja perhepalveluiden moniammatillisessa verkostoyhteistyössä. Moniammatillinen verkostoyhteistyö on lapsi- ja perhepalveluiden oleellinen toimintamalli lapsen ja/tai perheen tuen tarpeen arvioinnissa, suunnittelussa ja seurannassa. Tutkimuksen tiedonantajina olivat kymmenen vanhempaa $(n=10)$ ja tiedonantajat olivat osallistuneet moniammatillisiin verkostotapaamisiin sekä kuntien että erikoissairaanhoidon lapsi- ja perhepalveluissa erään maakunnan alueella. Aineisto kerättiiin avoimella haastattelulla ja analysoitiin sisällön analyysillä.

Tämän tutkimuksen perusteella lapsi- ja perhepalveluiden moniammatillinen verkostoyhteistyö parhaimmillaan tukee vanhempia ja luo vahvan pohjan hyvälle asiakassuhteelle. Asiakaslähtöisyyden toteutumisen perustana nähtiin vanhemman osallistaminen verkostoyhteistyöprosessiin ja verkostoyhteistyön suunnittelu, tiedonkulku ja ammattilaisten yhteistyöosaaminen. Puutteet verkostoyhteistyöprosessin suunnittelussa ja arvioinnissa yhdessä vanhemman kanssa sekä riittävässä tiedonkulussa ja vanhemman osallistamisessa verkostoyhteistyöhön koettiin verkostoyhteistyön haasteina. Tutkimus tuottaa uutta tietoa, jota voi hyödyntää moniammatillista verkostoyhteistyötä kehitettäessä. Tutkimus tuottaa tärkeää tietoa myös moniammatillisen verkostoyhteistyön koordinoimiseen ja sen kehittämiseen.

ASIASANAT: asiakaslähtöisyys, moniammatillisuus, verkostoyhteistyö, lapsi- ja perhepalvelut

HEIDI LAITILA, NINA LUNKKA, MARJO SUHONEN

\section{YDINASIAT}

- Aikaisempi tutkimus on osoittanut, että moniammatillisesti toteutetusta verkostoyhteistyöstä asiakkaiden ja asiakaslähtöisyyden näkökulmasta ei ole juurikaan tehty tutkimusta vaan tutkimukset ovat kohdistuneet ammattilaisten yhteistyöprosesseihin, joissa asiakas ei ole itse yleensä mukana.

- Tämä tutkimus toi esille, että lapsi- ja perhepalveluiden moniammatillinen verkostoyhteistyö parhaimmillaan tukee vanhempia ja luo hyvän pohjan yhteistyösuhteelle. Asiakaslähtöisyyden toteutumisen perustana nähtiin vanhemman osallistaminen verkostoyhteistyöprosessiin ja verkostoyhteistyön suunnittelu, tiedonkulku ja ammattilaisten yhteistyöosaaminen.

- Tämän tutkimuksen tuloksia voi hyödyntää moniammatillisen verkostoyhteistyön kehittämisessä ja sen koordinoimisen kehittämisessä.

- Tieteellisessä tutkimuksessa tulisi ottaa huomioon tarve asiakkaan näkökulman esiin tuomiselle, jotta moniammatillista verkostoyhteistyötä voidaan kehittää asiakaslähtöisyyden näkökulmasta. 


\section{JOHDANTO}

Kuntien sosiaali- ja terveydenhuollon sekä erikoissairaanhoidon lapsi- ja perhepalveluissa tehdään lapsi- ja perhekohtaisen työn lisäksi moniammatillista verkostoyhteistyötä verkostotapaamisissa. Moniammatillisella verkostoyhteistyöllä pyritään vastaamaan sellaisiin haasteisiin lasten ja perheiden asioissa, joihin tarvitaan laaja-alaista yli hallintorajojen ulottuvaa näkökulmaa ja joissa yksittäisen ammattilaisten apu ei ole enää riittävää. Moniammatillisia verkostotapaamisia järjestetään yleensä erityislapsen hoitoon, tutkimukseen ja kuntoutukseen, lastensuojelun ja perhetyön asiakkaan, mielenterveys- ja/tai päihdetyön asiakkaan sekä oppilashuollollisen asian hoitamisessa. Lapsi ja perhe on yhtäältä moniammatillisen verkostoyhteistyön asiakas, mutta toisaalta myös oleellinen toimija verkostoyhteistyössä. Vaikuttava moniammatillinen verkostoyhteistyö edellyttää ammattilaisen ja asiakkaan välisen yhteistyön sekä ammattilaisten välisen koordinoinnin lisäksi yhteistyön kehittämistä (42). Toimintamallina moniammatillinen verkostoyhteistyö on ollut viime vuosina useissa sosiaali- ja terveydenhuollon palveluissa, myös lapsi ja perhepalveluissa, yhtenä keskeisenä kehittämiskohteena.

Sosiaali- ja terveysalan kontekstissa verkostotyötä on aikaisemmin tutkittu muun muassa moniammatillisuuden fasilitoinnin ja vahvistamisen (46), ammattilaisten identiteetin (45), eri toimijoiden oppimisen, laadun kehittämisen ja tieteellisen tiedon käytäntöön siirtämisen näkökulmasta (47). Tässä tutkimuksessa huomio kohdennetaan verkostossa toimivien toimijoiden väliseen yhteistyöhön asiakkaan eli vanhemman näkökulmasta, minkä vuoksi artikkelissa käytetään käsitettä verkostoyhteistyö. Verkostoyhteistyö määritellään tässä yhteydessä lapsi- ja perhepalveluissa toimivien ammattilaisten sekä vanhempien ja/ tai perheiden väliseksi yhteistyöksi, jossa kontekstina on verkostotapaaminen.

Moniammatillinen verkostoyhteistyö asiakaslähtöisyyden näkökulmasta näyttäytyy kompleksisena ilmiönä. Käsitteellisistä lähtökohdista tarkasteltuna verkostoyhteistyö, moniammatillisuus ja asiakaslähtöisyys sisältävät samoja elementtejä. Neuvotteleminen, luottamus, sitoutuminen ja joustavuus $(31,35,41)$, asiakkaan osallisuus päätöksenteossa $(2,6,7,30)$ ja yhteistyökumppanuus $(5-7,23)$ ovat ulottuvuuksia, joita aikaisempi tutkimuskirjallisuus verkostoyhteistyöstä, moniammatillisuudesta ja asiakaslähtöisyydestä on tunnistanut. Vaikka asiakaslähtöisyys, moniammatillisuus ja verkostoyhteistyö esiintyvätkin usein samoissa yhteyksissä ja ne kietoutuvat vahvasti toisiinsa, moniammatillisesti toteutetusta verkostoyhteistyöstä ei ole juurikaan tehty tutkimusta asiakkaiden ja asiakaslähtöisyyden näkökulmasta. Tutkimukselliset intressit ovat kohdistuneet pääasiallisesti ammattilaisten yhteistyöprosesseihin, joissa asiakas ei ole itse mukana (19). Asiakkaan kuuleminen ja osallistuminen nähdään kuitenkin tärkeänä $(17,21)$ ja asiakkaan kanssa tehtävää yhteistyötä halutaan kehitettävän (18).

Terveydenhuollossa asiakkuutta on tutkittu suhteellisen vähän (44). Myöskään tutkimus asiakaslähtöisyydestä ei ole kohdistunut terveydenhuollon asiakkaiden ja potilaiden näkökulmaan (4), vaan se on sitä vastoin kohdistunut organisaatioiden ja johtamisen näkökulmaan $(8-12,44)$ ja terveydenhuollon henkilöstön näkökulmaan (3, 13-16). Asiakaslähtöisyyttä korostava johtaminen painottaa asiakkaan asemaa, näkökulmaa ja tarpeita ja sen on todettu vaikuttavan myönteisesti sekä organisaation asiakaslähtöiseen toimintaan että asiakaslähtöisen toiminnan kehittämiseen (2, 4). Myös useat Sipilän (1) hallituksen kärkihankkeet nostivat asiakaslähtöisyyden yhdeksi lähtökohdaksi palveluiden kehittämisessä. Hankkeissa korostettiin asiakaskokemusten ja -palautteiden huomioimista palveluiden ja toimintojen kehittämisessä sekä asiakkaan osallistamista ja ammattilaisten yhdessä toimimista asiakkaan hyväksi. (1.)

\section{MONIAMMATILLINEN VERKOSTOYHTEISTYÖ JA ASIAKASLÄHTÖISYYS}

Verkostotyön, verkostoyhteistyön ja moniammatillisen verkostoyhteistyön määrittely on aikaisemmassa tutkimuskirjallisuudessa moninaista ja sitä ohjaa tutkimustehtävän lisäksi usein tutkimuskonteksti. Tässä yhteydessä moniammatillista verkostoyhteistyötä avataan verkoston, verkostotyön sekä moniammatillisuuden käsitteiden kautta. Verkostotyön ja verkostoyhteistyön käsitteet esiintyvät tutkimuskirjallisuudessa usein rinnakkaisina ja tässä tutkimuksessa ne ymmärretään toistensa synonyymeina.

Verkostoyhteistyön taustalla on verkoston käsite, jota käytetään, kun puhutaan eri toimintajärjestelmien ja organisaatioiden kyvystä ylit- 
tää erilaisia rajoja fyysisissä ja sosiaalisissa tiloissa (35). Verkostot jaetaan ihmisten välisiin sosiaalisiin verkostoihin ja organisaatioiden välisiin verkostoihin. Sosiaali- ja terveydenhuollon moniammatilliset tiimit ovat hierarkkisessa ympäristössä toimivia verkostoja. (36.) Verkostojen avulla voidaan etsiä yhteisyyttä, vahvistaa toimijoiden toimijuutta sekä nostaa esiin resursseja ja voimavaroja, jotka eivät ole vielä käytössä (37).

Verkostoyhteistyön ja verkostotyön käsitteiden välinen erottelu voidaan nähdä osin keinotekoisena, koska verkosto metaforana painottaa yhteistyön näkökulmaa, jossa oleellista on sosiaalisten järjestelmien toiminnallisuus ja niissä tapahtuva vuorovaikutus (35). Verkostotyön synonyymeina on puolestaan käytetty tiimityötä, moniammatillista yhteistyötä ja kumppanuuksien rakentamista (35). Hyvä verkostotyöskentely edellyttää luottamuksen ja sitoutumisen (31, $35,41)$ lisäksi verkostotyöskentelyprosessin, verkoston tiedonsiirron ja verkoston dynaamisuuden arviointia verkoston toiminnan aikana. Toiminnan suunnittelu, toteutus ja arviointi sekä toimiminen arvioinnin perusteella ovat asioita, jotka sisältyvät verkostoyhteistyöhön. Suunnittelu pitää sisällään muun muassa toimintasuunnitelman, toteutus puolestaan suunnitelman käyttöönoton, arviointi sitä vastoin työn onnistumisen ja sen vaikutusten arvioinnin sekä toimiminen arvioinnin perusteella esimerkiksi toimintamallien parantamisen. Tiedonsiirron mahdollistaminen on yksi verkostoyhteistyön kulmakivi, vaikkakin sen toteutuminen nähdään käytännössä aina haasteena. Jokaisella verkoston toimijalla on tiedonsiirron toteutumisessa vastuu. (35.) Riittävä tiedonsiirto myös lisää luottamusta verkoston eri toimijoiden keskuudessa (41). Lisäksi verkostot nähdään etenkin sosiaalija terveysalalla hyvin dynaamisina, joka puolestaan parhaimmillaan mahdollistaa uusien näkemysten mukaan ottamisen, mutta pahimmillaan vaurioittaa toimijoiden välistä luottamusta ja sitoutumista (35).

Myös moniammatillisuuden käsitteeseen sisältyy oletus yhteistyöstä, perustuuhan moniammatillisuuden tarkastelu yhteistyötä tai tiimejä koskeviin käsitteisiin. Yhteistyöhön liittyy keskeisinä käsitteinä jakaminen, kumppanuus, keskinäinen riippuvuus ja valta. (23.) Yhteistyön toteutumisen edellytyksiä ovat puolestaan yhteistyörakenteet ja yhteistyöprosessit. Yhteistyö- rakenteisiin liittyy johtamiskulttuuri, resurssit ja koulutus, kun taas yhteistyöprosessit sisältävät yhteisen päämäärän, toisen työn tuntemisen, vuorovaikutustaidot, työnjaon määrittelemisen ja oman asiantuntijuuden sisäistämisen. (7, 17, 19, 22, 32, 33.) Erityisesti yhdyspinnat ylittävässä yhteistyössä on tärkeää eri osapuolten roolien ja vastuiden määritteleminen, jolloin kukin ammattilainen toimii oman ammatillisen osaamisensa puitteissa (19). Tässä työskentelymuodossa vaaditaan vapautumista ammatillisista rooleista ja tarvitaan perehtymistä toisen ammattilaisen näkökulmaan $(7,34$.)

Moniammatillinen yhteistyö sosiaali- ja terveydenhuollon verkostoissa sisältää samoja elementtejä kuin moniammatillinen yhteistyö ylipäänsä. Sosiaali- ja terveydenhuollon tutkimuksissa moniammatillista yhteistyötä on määritelty useista näkökulmista. Aikaisempi tutkimuskirjallisuus on osoittanut, että moniammatillinen yhteistyö on erilaisen koulutuksen saaneiden ammattilaisten kykyä tuoda erityisosaaminen ja tieto yhteiseen käyttöön $(31,33)$, joustavaa kohtaamista asiakkaiden ja toisten ammattiryhmien edustajien kanssa (31) sekä asiakas- ja potilaslähtöistä työskentelyä (30), jossa oleellista on ammattilaisten välinen vuorovaikutus tiedon jakamisen ja yhdessä työskentelyn korostuessa (20, 23). Esteenä yhteistyölle ovat haasteet ammattilaisten yhteistyöosaamisessa ja asenteissa (17, 43), tieto-taidossa ja ajanpuutteessa (17), yhteisen päämäärän puuttumisessa, vastuu- ja valtakysymyksissä, ammattilaisten näkemyseroissa (19) sekä asiakaslähtöisyydessä ja asiakkaan osallistamisessa yhteistyöhön (7). Myös ammattilaisten eriävät käsitykset ryhmätyöstä ja lääketieteellinen valta-asema (32) sekä ammatillisiin rooleihin liittyvät kysymykset, työtehtävien määrittäminen ja yhteisen tiedon puute nähdään haasteena moniammatilliselle yhteistyölle (43). Moniammatillisen yhteistyön kehittämisessä nähdään tärkeänä laajempi hallinnollinen konteksti (42) sekä hallinnon merkitys moniammatillisen yhteistyön toimintaperiaatteiden luomisessa, seurannassa ja arvioinnissa sekä täydennyskoulutuksen järjestämisessä (7). Myös moniasiantuntijuuden määritelmä on lähellä moniammatillisuuden määritelmää, mutta siinä korostuu enemmän asiakkaan tasavertaisuus toimijana ja kumppanina asioiden hoitamisessa sen sijaan, että toiminta olisi enemmän työntekijälähtöistä 
(7). Moniasiantuntijuus on jalostuneempi käsite, jossa asiakas huomioidaan oleellisemmin ja näin nähdään aito asiakaslähtöinen näkökulma toiminnan perustana (22). Tässä tutkimuksessa pitäydytään moniammatillisuuden määritelmässä, koska verkostoyhteistyössä nähdään työntekijälähtöisyyden korostuvan yhteistyöprosessin eri vaiheissa.

Moniammatillinen verkostoyhteistyö verkostotapaamisissa, joissa asiakas on mukana tasavertaisena osallistujana, edellyttää myös asiakaslähtöisyyden käsitteellistä tarkastelua. Asiakaslähtöisyyden käsite määrittyy pitkälle asiakkuus -käsitteeseen. Asiakkuus sosiaali- ja terveydenhuollossa perustuu oikeudelliseen sääntelyyn, kuluttajuuteen ja hallinnolliseen näkökulmaan. Oikeudellista sääntelyä määrittävät muun muassa asiakkaan oikeudet. Kuluttajuus puolestaan perustuu muutokseen, jossa sosiaali- ja terveyspalveluiden käyttäjistä on tullut asiakkaita. Siinä ydinajatuksena on, että palvelujen käyttäjällä tulee olla mahdollisuus palveluiden kehittämiseen, suunnitteluun ja tuottamiseen. Hallinnollinen näkökulma sitä vastoin tarkoittaa organisaation määritelmää asiakkaasta sekä sitä, millä tavalla asiakkaaseen suhtaudutaan hallinnollisissa käytännöissä ja toimintatavoissa. (2.)

Sosiaali- ja terveydenhuollon tutkimuksissa asiakaslähtöisyyttä on määritelty tasa-arvoiseksi vaikuttamiseksi (5), asiakkaan aktiiviseksi osallistumiseksi itseään koskevaan päätöksentekoon $(2,6,7)$ ja yhteistyökumppanuudeksi (5-7), mikä edelleen edellyttää sosiaali- ja terveydenhuollossa asiakkaan ja hänen omaisensa osallistumista hoitoa koskevaan päätöksentekoon (7). Asiakaslähtöisyys sitä vastoin voi toteutua kolmella eri tasolla, joita ovat organisaatioiden asiakaslähtöinen toiminta, asiakaslähtöinen yhteistyösuhde ja asiakaslähtöisesti työskentelevän ammattilaisen toiminta (4). Tässä tutkimuksessa tarkastellaan vanhempien kokemuksia moniammatillisista verkostotapaamisista asiakaslähtöisyyden näkökulmasta ja asiakaslähtöisyys määritellään sen toteutumisen kautta (4).

\section{TUTKIMUKSEN TARKOITUS, TAVOITE JA TEHTÄVÄ}

Tämän tutkimuksen tarkoituksena on kuvata vanhempien kokemuksia moniammatillisista verkostotapaamisista asiakaslähtöisyyden näkökulmasta. Tutkimuksen tavoitteena on tuottaa tietoa asiakaslähtöisyyden toteutumisesta lapsi- ja per- hepalveluiden moniammatillisessa verkostoyhteistyössä. Tulosten avulla voidaan kehittää lapsi- ja perhepalveluiden moniammatillista verkostoyhteistyötä ja moniammatillisen verkostoyhteistyön koordinointia asiakkaan näkökulmaa huomioivammaksi. Tutkimuksen tuloksia voidaan myös hyödyntää sosiaali- ja terveydenhuollon koulutuksessa moniammatillista verkostoyhteistyötä tarkasteltaessa. Tutkimuskysymyksenä oli: Millaisia kokemuksia vanhemmilla on moniammatillisista verkostotapaamisista asiakaslähtöisyyden näkökulmasta?

\section{TUTKIMUSAINEISTO JA -MENETELMÄT}

\section{TIEDONANTAJAT JA AINEISTON KERUU}

Tämä tutkimus kohdentui verkostoyhteistyöhön, jossa tutkimuskontekstina oli verkostotapaaminen. Tutkimuksen tiedonantajat olivat vanhempia, jotka olivat osallistuneet moniammatillisesti toteutettuihin verkostotapaamisiin sekä kuntien sosiaali- ja terveydenhuollon että erikoissairaanhoidon lapsi- ja perhepalveluissa erään maakunnan alueella. Tiedonantajien valinta tapahtui siten, että kuntien johtavat viranhaltijat pyysivät lapsi- ja perhepalveluiden työntekijöitään informoimaan asiakkaitaan tutkimuksesta ja pyytämään heitä osallistumaan siihen. Myös tutkija itse osallistui tiedonantajien informoimiseen ja rekrytoimiseen. Tutkija oli laatinut saatekirjeen, jossa kerrottiin tutkimuksesta. Lapsi- ja perhepalveluiden työntekijöillä oli mahdollisuus antaa saatekirje tiedonantajille ennen tutkimukseen suostumista. Tutkimukseen osallistuivat ne kaikki tiedonantajat, jotka ilmaisivat suostumuksensa. Ennen aineiston keruuta haastateltavilta pyydettiin kirjallinen suostumus osallistumisestaan sekä tuotiin esiin haastateltavan anonymiteetin suojaaminen (25). Haastateltaville kerrottiin tutkimuksen tarkoituksesta ja annettiin riittävä informaatio tutkimuksesta sekä siihen osallistumisen vapaaehtoisuudesta (40). Tiedonantajista yhdeksän oli naisia ja yksi mies, jotka olivat iältään 23-51 -vuotiaita ja yhteensä heitä oli kymmenen.

Aineisto kerättiin avoimella haastattelulla (24) keväällä 2018 kuntien tiloissa ja asiakkaiden kodeissa neljän kuukauden aikana sen mukaan, mikä oli tiedonantajalle luontevin paikka toteuttaa haastattelu. Haastattelut toteutettiin yksilöhaastatteluina. Haastatteluun varattiin jokaiselle 
haastateltavalle tunti aikaa ja yhden päivän aikana tehtiin enintään kaksi haastattelua. Haastatteluun varattu aika osoittautui esihaastatteluiden pohjalta riittäväksi (25). Haastattelu aloitettiin yhdellä avoimella kysymyksellä, jossa pyydettiin tiedonantajia kertomaan millaisia kokemuksia heillä on asiakaslähtöisyydestä moniammatillisissa verkostotapaamisissa. Haastattelut kestivät 12 minuutista - 57 minuuttiin ja ne nauhoitettiin. Tutkimusaineisto muodostui nauhoitetuista haastatteluista, jotka litteroitiin sanatarkasti. Litteroitua aineistoa oli yhteensä 68 sivua (A4), fonttikoko 12 ja riviväli 1,5 .

\section{AINEISTON ANALYYSI}

Aineisto analysoitiin aineistolähtöisesti induktiivisella sisällön analyysillä, koska aiheesta ei ole aikaisempaa tutkimustietoa (26). Analyysissa tutkija keskittyi niihin merkityssisältöihin, mitä tutkimuskysymys edellytti $(27,28)$. Aluksi aineisto luettiin useaan kertaan, jotta aineisto tuli tutuksi. Sen jälkeen aineistosta alleviivattiin ajatuskokonaisuudet, jotka vastasivat tutkimustehtävään. Ajatuskokonaisuudesta, joka kuvasi vanhempien kokemuksia, muodostui tutkimuksen analyysiyksikkö. Alleviivatut kohdat pelkistettiin ja samansisältöiset ilmaukset ryhmiteltiin alaluokkiin, minkä jälkeen alakategoriat nimettiin niiden sisältöjen mukaan. Sen jälkeen alakategorioita yhdistettiin sisältöjen mukaan yläkategorioihin ja annettiin yläkategorioille nimet. Lopuksi tehtiin yhdistävät luokat. $(26,29$.) Aineiston ja tutkimusmenetelmien luotettavuuteen liittyvät pohdinnat esitetään oman otsakkeensa alla tutkimuksen lopussa.

Tutkimuksen tuloksista nousi esiin kolme yhdistävää luokkaa, jotka kuvaavat vanhempien kokemuksia moniammatillisista verkostotapaamisista asiakaslähtöisyyden näkökulmasta. Yhdistävät luokat ovat vanhemman osallisuus verkostoyhteistyössä, moniammatillisen verkostoyhteistyön haasteet asiakaslähtöisyyden näkökulmasta ja moniammatillisen verkostoyhteistyön kehittämiskohteet vanhempien näkökulmasta. Näistä muodostui tutkimuksen pääluokka: Moniammatillinen lapsi- ja perhepalveluiden verkostoyhteistyö vanhempien kokemana. Tulokset kuvataan yhdistävien luokkien mukaan (kuvio1).

\section{TUTKIMUKSEN TULOKSET}

\section{VANHEMMAN OSALLISUUS VERKOSTOYHTEISTYÖSSÄ}

Lähes jokaisella tähän tutkimukseen osallistuneella vanhemmalla oli kokemusta useammasta kuin yhdestä verkostotapaamisesta lapsi- ja perhepalveluissa. Vanhempien kokemukset verkostotapaamisista olivat pääsääntöisesti hyviä. Vanhemmat kokivat tulleensa kuulluiksi ja huomioiduiksi moniammatillisissa verkostotapaamisissa sekä kokivat olevansa arvostettuja vanhempina. Yhteistyö ammattilaisten kanssa koettiin tärkeäksi, taitavaksi ja huomioivaksi. "Minulla on hyviä kokemuksia vanhempana, että minä tulen kuulluksi -kysytään vanhempien mielipiteitä ja näkemyksiä ja toiveita -".

Ammattilaisten kanssa käytyjä keskusteluja pidettiin hyvin merkittävinä; ne olivat helppoja, huojentavia, kannustavia ja rohkaisevia. Vanhemman mahdollisuus keskustella verkostoon osallistuvan kanssa etukäteen auttoi myös osallistumaan verkostoon. Vanhemmat myös kokivat, että heidän oma näkemyksensä lapsen tai perheen asioista sai vahvistusta verkostossa. Ammattilaisten taitoa hoitaa asiakkaiden asioita arvostettiin paljon. Vanhemmat kertoivat, että ammattilaisiin voi olla aina yhteydessä, he järjestävät apua, kun sitä tarvitaan, ottavat monipuolisesti huomioon eri asiat palvelutarpeen arvioinnissa eikä heillä ole ennakkoasenteita. Myös se koettiin tärkeänä, että ammattilaiset ovat tarpeeksi tietoisia lapsen asioista verkostotapaamisissa ja että verkostossa toimivat ammattilaiset auttavat vanhempia eri tukimuotojen äärelle. Vanhemmat ymmärsivät hyvin ammattilaisten välisen yhteistyön myös verkostotapaamisten ulkopuolella ja pitivät sitä tärkeänä, jotta kaikilla olisi oleellinen tieto lapsen ja perheen asioista verkostotapaamiseen tultaessa. Verkostossa tapahtuneiden vaikeiden päätösten yhteydessä ammattilaisen taito kohdata vanhempi koettiin merkittävänä.

\footnotetext{
"Siinä tilanteessa, kun tehtiin kiireellinen päätös huostaanotosta, niin useampikin sosiaalityöntekijä kävi taputtelemassa olalle ja sanomassa, ettei me jätetä teitä yksin. Niin kyllä se silloin lohdutti."
}

Vanhemmat kokivat, että he pystyivät osaltaan vaikuttamaan verkostotapaamisten järjestämiseen. Suurin osa tiedonantajista oli sitä mieltä, 
että heidän mielipidettä kysyttiin, kun mietittiin verkostotapaamiseen osallistuvia ammattilaisia. Vanhemmilla oli myös kokemus, että verkostotapaamisessa pohdittiin yhdessä tavoitteita lapsen tai perheen asioissa. Vanhemmat kuitenkin kokivat, että heillä itsellään oli iso rooli asioiden tiedottamisessa ja lapsen tai perheen hoidon sekä vanhemman kuuntelemisen toteutumisessa. Yksi tiedonantaja kuvasi vanhemman aktiivisuuden merkitystä näin: "jos me vanhemmat ei oltaisi oltu niin aktiivisia, niin tilanne ei olisi niin byvä tällä hetkellä.” Toinen vanhempi kuvasi asiaa puolestaan näin: "eihän sinua muuten kuunnella, jos et itse tuo asiaa ääneen esiin." Vanhemman toiveet verkostotapaamisten ja muiden tukimuotojen jatkamisesta myös huomioitiin verkostotapaamisiin osallistuvien ammattilaisten taholta.

\section{MONIAMMATILLISEN VERKOSTOYHTEISTYÖN HAASTEET ASIAKASLÄHTÖISYYDEN NÄKÖKULMASTA}

Ammattilaisten välisen tiedonsiirron vähäisyys sekä asiakkaiden määrä vaikuttivat vanhempien kokemana verkostotapaamisen onnistumista vähentävästi. Tämä ilmeni siten, että verkostotapaamisessa ei ollut ammattilaisilla käytettävissä kaikkea sitä tietoa, minkä vanhempi olisi toivonut heillä olevan.

"Mutta kun ne (lastensuojelu ja perhetyö) eivät puhu keskenään asioista, se on huono puoli siinä, kun tuntuu, että lastensuojelu ei tiedäkään ihan kaikkea, kun perhetyö ei ole kertonut.”

Vanhemman ja ammattilaisen tai eri ammattilaisten kesken olevien näkemyserojen yhteydessä ammattilaisten toiminta vaihteli asiakkaan näkemystä kunnioittavasta ja huomioivasta tavasta asiakkaan näkemyksen huomioimatta jättämiseen. Joskus ristiriitainen näkemys johti asiakassuhteen katkeamiseen. Muutamalla vanhemmalla oli kokemusta siitä, että ristiriitatilanteissa kuunneltiin vanhempaa hyvin ja tehtiin päätös yhteisymmärryksessä, mutta oli myös vanhempia, joilla oli kokemusta lääkärin auktoriteetista suhteessa muihin verkoston jäseniin. Tässä tilanteessa yksi vanhempi koki, että lääkärin pitkä kokemus ja hänen arvostuksensa vaikuttivat lääkärin toimintaan siten, että tiimityön merkitys ei ollut ensisijainen. ”Jos kaikki tekee tiiminä, niin sen pitäisi minun mielestä lääkärinkin tehdä ja kuunnella.”
Vanhempien mielestä verkostotapaamisten onnistumisessa oli tärkeää, että verkostoon osallistuvat ymmärsivät verkostoyhteistyön merkityksen.

Vanhemmat toivat myös esiin joidenkin lääkäreiden sopimattomia toimintatapoja verkostotapaamisessa, vaikkakaan se ei aina vaikuttanut muiden ammattilaisten toimintaan eikä verkostotapaamisen onnistumiseen. Epäasiallisuus oli vanhempien mukaan lapseen liittyvän tiedon paikkaansa pitämättömyyttä ja lapsen hoitohistorian sivuuttamista.

\begin{abstract}
”Tuntui, että hän on jotenkin ylempänä ja se oli jotenkin ahdistavaa, kun hän oli usein tietävinään meidän asioista paremmin kuin mitä hän tiesi -- hän ei nähnyt meitä kuin harvoin ja silti saattoi kirjoittaa papereihin sellaista mikä ei välttämättä pitänyt paikkaansa muidenkaan työntekijöiden mielestä. Sitä oli semmoinen altavastaaja.”
\end{abstract}

Ristiriitoja muiden ammattilaisten ja vanhempien välillä aiheuttivat useimmiten vanhemman tukemiseen liittyvät asiat.

"Esimerkiksi justiin sellaiset, että jotkut arvioivat minun tuen tarvetta hirveän paljon yli ja ovat huolissaan siitä, miten minä pärjään -- saattaa tulla semmoinen tunne, että kuin huonona ne minua pitää.”.

Pääsääntöisesti vanhemmat kuitenkin kokivat, että ammattilaisten näkemykset verkostotapaamisissa olivat yhteneväisiä ja asioista pystyttiin sopimaan kaikkien mielipiteet huomioiden.

Vanhemmilla oli kokemuksia useanlaisista verkostotapaamisista eri palveluissa. Eräs vanhempi kertoi kokemuksestaan, jossa hän oli odottanut oven ulkopuolella verkostotapaamisen alkamista tietäen, että ammattilaiset kokoontuivat sitä ennen ilman vanhempaa pitämään viranomaisverkostotapaamiseen. Vanhemman kokemus tästä verkostotapaamisesta ei ollut hyvä, koska hän ei kokenut menevänsä tasavertaisena osallistujana mukaan, kun ammattilaiset olivat jo keskenään pitäneet tapaamisen.

”Jos minä vertaan kahta tilannetta, että jossa minä tiedän, että toiset ovat jo tavanneet ennen minua verrattuna siihen, että me mennään kaikki yhdessä yhtä aikaa, niin ehdotto- 
masti se toinen vaihtoehto on parempi. Mutta näissä tapaamisissa kuitenkin on aina itsellä puheenvuoro."

Verkostotapaamisten suunnittelu oli vanhempien kokemana ammattilaislähtöistä. Lähes kaikilla vanhemmilla oli kokemus siitä, että verkostotapaamisia ei suunniteltu etukäteen muutoin kuin ajan ja paikan sopimiseksi. Tarkempaa sopimusta verkostotapaamisessa käsiteltävistä asioista ei tehty, vaan yleensä jatkettiin siitä, mihin edellisellä kerralla oli jääty tai mikä oli sillä hetkellä ajankohtaista. Kahdelle vanhemmalle oli ennen verkostotapaamisia tullut saatekirje, jossa oli tieto käsiteltävistä asioista ja vanhemmilla oli myös mahdollisuus puhelimitse tuoda etukäteen tietoon, jos heillä itsellään oli jotain lisättävää. Eräs vanhempi koki, että etukäteen saatu tieto käsiteltävistä asioista voisi helpottaa verkostotapaamiseen osallistumista ja mahdollistaisi tapaamiseen valmistautumisen.

"Koska joskus joku saattaa yhtäkkiä kysyä jotain mitä en ole ehkä miettinyt siihen palaveriin liittyen, niin sitten minä menen ihan lukkoon ja en tiedä mitä minä vastaan (...) minä saatan etukäteen panikoida, että mistä siellä puhutaan ja mitähän ne kysyy”.

Moniammatillisten verkostotapaamisten kokoonpanot sekä niissä käsiteltävät asiat olivat hyvin erilaisia. Useimmiten verkostotapaamiset liittyivät erityislapsen hoitoon, tutkimukseen ja kuntoutukseen, lastensuojelun ja perhetyön asiakkaan, mielenterveys- ja/tai päihdetyön asiakkaan taikka oppilashuollollisen asian hoitamiseen. Verkostotapaamisissa oli mukana laajasti eri ammattilaisia. Vanhempien kokemus oli, että tapaamisissa olivat oikeat ihmiset paikalla ja kokoonpanoja pohdittiin ja tarvittaessa vaihdettiin yhteistyöprosessin eri vaiheissa. Uusien ammattilaisten mukaan tulo vaikeutti hetkellisesti verkoston toimintaa, mutta kaikkien läsnäolijoiden mukana olo koettiin tärkeänä, jolloin laaja-alainen asiantuntemus vahvistui. Ammattilaisten jatkuva vaihtuminen kuitenkin koettiin epämieluisana.

”Jotenkin tässä parin vuoden aikana, kun meillä on ollut moniammatillista perhetyötä ympärillä, niin kaikista hankalinta on ollut se, kun porukka vaihtuu tiuhaan tahtiin, niin sii- nä ei itsekään ole perillä ketä siellä kaikkia on ja ketä siihen kuuluu -- varsinkin silloin, kun on ollut kaikkein rankinta tämä elämäntilanne, niin silloin kun on vaihtunut ja aina kertoa kaikki alusta asti uudestaan kaikki asiat, niin se on välillä ollut tosi rankkaa.”

Vanhemmilla oli myös kokemusta siitä, että he olivat joutuneet itse pyytämään mielenterveystyön ammattilaista mukaan verkostotapaamiseen. Lisäksi yksi vanhempi koki, että mitä enemmän on ammattilaisia paikalla, sitä enemmän häntä ahdistaa mennä verkostotapaamiseen. Haasteita toi myös aikataulujen yhteensovittaminen, mutta silloin koettiin tärkeänä, että verkostotapaamiseen osallistuvilla oli käytettävissä se tieto, jonka verkostotapaamiseen estynyt ammattilainen olisi muutoin tuonut.

\section{MONIAMMATILLISEN VERKOSTOYHTEISTYÖN KEHITTÄMISKOHTEET VANHEMPIEN NÄKÖKULMASTA}

Vanhemmat toivat esiin asioita, joita olisi heidän mukaan hyvä huomioida verkostoyhteistyössä. Vanhempien mukaan kynnys verkostotapaamisten järjestämiseen ja muihin palveluihin olisi hyvä pitää matalana. Ammattilaisilta toivottiin myös asioiden esiin tuomista lempeästi ja tasavertaisesti suhteessa vanhempiin.

"En minä nyt sanoisi, että siinä mitenkään erityisesti olisi parantamisen varaa, mutta se minusta on justiin, että olisi semmoinen matala kynnys, että ei vanhempana ottaisi turhia paineita, että se viesti tulisi semmoisena lempeänä eikä sellaisena ylhäältä päin”.

Myös ohjaavaa, kannustavaa ja vanhempia nostavaa otetta toivottiin.

Vanhemmat myös toivoivat, että ammattilaiset antaisivat verkostotapaamisissa käytännön ohjeita ja vinkkejä arjessa selviytymiseen. Lisäksi vanhemmat toivat esiin toiveen mahdollisuudesta keskustella verkostotapaamisiin osallistuvien ammattilaisten kanssa ennen verkostotapaamista, jolloin se voisi auttaa vanhempaa valmistautumaan keskusteltaviin asioihin. Myös keskustelut ammattilaisten kanssa ilman lapsen läsnäoloa tulivat esiin vanhempien toiveina, koska aina ei voi lapsen kuullen kaikista asioista puhua.

Vanhemmat toivat esiin myös lähiverkoston merkityksen ja sen huomioimisen moniammatil- 


\section{Moniammatillinen lapsi- ja perhepalveluiden verkostoyhteistyö vanhempien kokemana}

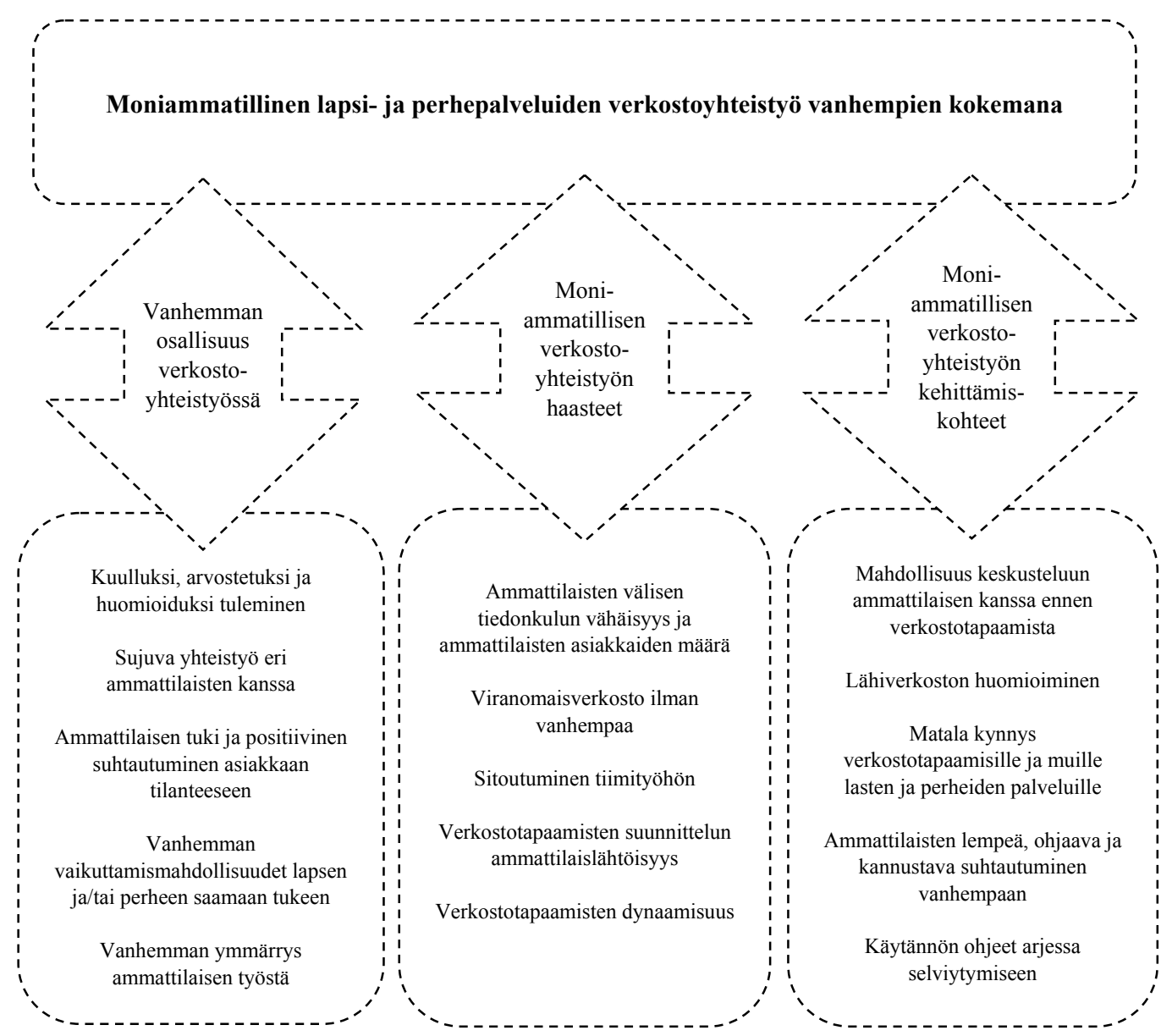

Kuvio 1. Tutkimuksen keskeiset tulokset

lisissa verkostotapaamisissa. Vanhemmat kokivat, että verkostotapaamisissa ammattilaiset huomioivat lähiverkostoa kysyen lähiverkoston mahdollisuuksia tukea perhettä eri keinoin, mutta vanhemmilta tuli myös toiveita, että koko perhe huomioitaisiin paremmin tuen tarvetta arvioitaessa.

"Sinällään niin kun se, että pitäisi ottaa koko perhe huomioon, ei vaan se lapsi, joka sairastaa ja se yksi vanhempi siellä, joka on mukana. Kun se lapsen sairaus koskettaa koko perhettä.”

Muutoin vanhempien toiveet kohdistuivat enemmän yksittäisiin palveluihin kuin itse verkostotapaamisiin. Vanhemmat kokivat, että ammattilaisten välinen vuorovaikutus toimi hyvin ja ammattilaiset olivat yleensä hyvin yksimielisiä asioista.
Ylipäätään vanhempien oli vaikeaa arvioida ammattilaisten toimintaa moniammatillisissa verkostotapaamisissa.

\section{POHDINTA}

\section{TULOSTEN TARKASTELU}

Moniammatillinen verkostoyhteistyö verkostotapaamisissa mahdollistaa laaja-alaisen asiantuntemuksen hyödyntämisen lapsi- ja perhepalveluiden asiakkaille. Parhaimmillaan moniammatillinen verkostoyhteistyö tukee vanhempia ja luo vahvan perustan hyvälle asiakassuhteelle. Verkostoyhteistyöprosessissa korostuu ammattilaisten vastuu, vaikka vanhemmalla on myös osuutensa verkostoyhteistyön onnistumisessa. Vanhemman osallistaminenverkostoyhteistyöprosessiin, verkostoyhteistyön suunnittelu, tiedonkulku ja ammattilaisten 
yhteistyöosaaminen nähdään tämän tutkimuksen mukaan asiakaslähtöisyyden toteutumisen perustana. Puutteet niiden toteutumisessa osoittautuivat asiakaslähtöisyyden toteutumisen esteeksi. Asiakkaan osallistaminen verkostoyhteistyöprosessiin (43) sisälsi asiakkaan osallistamisen verkostoyhteistyön suunnitteluun ja kehittämiseen, asiakkaan osallistamisen huomioimisen verkostoyhteistyöprosessin eri vaiheissa ja asiakkaan toimijuuden vahvistamisen (37) verkostoyhteistyössä. Verkostoyhteistyön suunnittelu (35), tiedonsiirto $(35,43)$ ja ammattilaisten yhteistyöosaaminen $(17,43)$ ovat myös tämän tutkimuksen mukaan asioita, jotka vanhemman kokemana kytkeytyvät asiakaslähtöisyyden toteutumiseen lapsi- ja perhepalveluiden verkostoyhteistyössä.

Tämän tutkimuksen mukaan vanhempien osallistuminen moniammatillisten verkostotapaamisten suunnitteluun ja kehittämiseen oli hyvin vähäistä. Vanhemmat pystyivät vaikuttamaan siihen, keitä verkostotapaamisiin osallistui, mutta muutoin suunnittelu ja kehittäminen jäi toteutumatta lähes kokonaan. Verkoston dynaamisuudesta keskustelu oli myös vähäistä. Vanhempien valmistautumista verkostotapaamisten dynaamisuuteen edesauttaisi etukäteinen keskustelu dynaamisuuden haasteista ja mahdollisuuksista, koska perheiden elämäntilanteet ovat usein hyvin haastavia. Verkostoyhteistyö sisältää verkostoyhteistyöprosessiin kuuluvien asioiden arvioinnin lisäksi myös verkoston toiminnan suunnittelun ja arvioinnin sekä verkoston dynaamisuuden arvioinnin. Verkostotyön dynaamisuus voi pahimmillaan vaikuttaa luottamuksen ja sitoutumisen vaurioitumiseen verkostotapaamiseen osallistuvien välisissä suhteissa, mutta se voi myös tuoda uusia mahdollisuuksia verkostoyhteistyöprosessille. (35.)

Puutteet riittävässä tiedonsiirrossa ja verkostotapaamisiin osallistuvien ammattilaisten sitoutumisessa ja yhteistyökumppanuudessa nousivat myös esiin vanhempien kokemuksista. Tiedonsiirtoon liittyvät haasteet ilmenivät käytettävissä olevan tiedon puuttumisena asioiden hoitamiseksi. Vanhemmilla ei myöskään ollut etukäteistietoa verkostotapaamisessa käsiteltävistä asioista, mikä olisi helpottanut verkostoon valmistautumista. Verkostotyössä jokaisella osallistujalla on vastuu tiedonsiirrosta ja se on yksi verkostotyön keskeinen tekijä (35). Riittävä tieto jokaisella verkostotapaamiseen osallistuvalla vähentää vanhemman ahdistusta osallistua verkostotapaamiseen ja mahdollistaa riittävän hyvän päätöksenteon, koska päätökset pohjautuvat oikeaan ja kaikille tasavertaiseen tietoon. Myös aikaisemmassa kirjallisuudessa yhteisen tiedon puute (43) ja tiedon siirron toteutuminen on nähty haasteena (35). Kuitenkin keskeisenä asiana moniammatilliselle yhteistyölle nähdään vuorovaikutteinen työskentelytapa, jossa tiedon jakaminen ja yhdessä työskentely korostuvat $(20,23)$. Verkostoyhteistyö mahdollistaa johdonmukaisena ja hyvin suunniteltuna toimintamallina resurssien tehokkaan käytön sekä vaikuttavuuden asiakkaiden asioiden hoitamiseksi, koska verkostoyhteistyöhön osallistuu useita eri ammattilaisia yhtä aikaa. Sen vuoksi verkostoyhteistyön koordinoiminen ja verkostotapaamisten valmisteleminen tulee ottaa keskeiseksi asiaksi verkostoyhteistyön kehittämisessä tavoitteelliseksi ja johdonmukaiseksi toimintamalliksi. Hyvin suunniteltu, johdonmukainen ja laaja-alaisen asiantuntemuksen sisältävä verkostoyhteistyö mahdollistaa asiakkaalle puolestaan tehokkaan ja vaikuttavan yhtäaikaisen palvelun.

Vanhempien kokemukset lääkärin auktoriteetista moniammatillisessa verkostotapaamisessa sekä muiden ammattilaisten ylireagoiminen lapsen tai perheen tuen tarvetta arvioitaessa olivat asioita, jotka osoittautuivat haasteiksi asiakaslähtöisyyden näkökulmasta. Vanhempien mukaan lääkärin auktoriteetti vaikutti toimintaan siten, että verkostoyhteistyötä ei nähty ensisijaisena, vaan päätökset pohjautuivat lääketieteellisen valta-aseman käyttöön. Tällainen toiminta näyttäytyi vanhemmille verkostoyhteistyön ymmärtämättömyytenä.

Lääketieteellinen valta-asema $(19,32)$, ammattilaisten eriävät käsitykset verkostotyöstä (32) ja ammatillisiin rooleihin liittyvät kysymykset (43) ovat tulleet esiin aikaisemmissa tutkimuksissa moniammatillisen verkostotyön haasteina. Lääkärien ammattikunnalla on vahvat perinteet suomalaisessa terveydenhuollossa. Lääkärin asemaa vallan käyttäjänä ei yleensä kyseenalaisteta. Tulevaisuuden sosiaali- ja terveydenhuollon muutos korostaa asiakaslähtöisyyttä (1). Lääkärin käyttämän vallan näyttäytyminen moniammatillisessa verkostoyhteistyössä tulee tiedostaa ja huomioida myös verkostoyhteistyön kehittämisen yhtenä osa-alueena. Lisäksi verkostoyhteistyön ymmärtämättömyys sekä ammatti- 
laisten ylireagoiminen voidaan nähdä ammattilaisten yhteistyöosaamiseen liittyvänä haasteena, joiden huomioiminen verkostoyhteistyön suunnittelussa ja kehittämisessä on keskeistä asiakaslähtöisyyden näkökulmasta. Ammattilaisten keskinäinen vuoropuhelu asiakkaan hoidon ja tuen tarpeesta voi helpottaa ammattilaisen tekemää tuen tarpeen arviointia, kun hänellä on käytettävissä toisen ammattilaisen näkökulma asiakkaan asioiden hoitamiseksi. Verkostoyhteistyön ymmärtäminen siihen osallistuvien ammattilaisten kesken on puolestaan verkostoyhteistyön elinehto, jotta asioita voidaan hoitaa asiakkaan parhaaksi.

Vanhemmat toivat esiin oman aktiivisuutensa merkityksen verkostoyhteistyön onnistumisessa. He kertoivat, että heillä itsellään on vahva rooli, jotta he tulevat kuulluiksi ja että tieto siirtyisi verkoston toimijoiden välillä. Tilanteessa, jossa vanhemman tulee itse huolehtia kuulluksi tulemisestaan, on vaarana asiakkaan osallisuuden väheneminen, jos vanhemmalla itsellään ei ole voimavaroja tuoda ääntään kuuluviin. Moniammatilliseen verkostotapaamiseen osallistuvien ammattilaisten on hyvä huomioida asiakkaan osallisuuden mahdollistaminen myös niille vanhemmille, joilla ei ole voimavaroja nostaa omia mielipiteitä esiin. Määtän (37) mukaan verkostotyöllä on mahdollista vahvistaa yksilöiden toimijuutta, jolloin moniammatilliseen verkostotapaamiseen osallistuvalta ammattilaiselta edellytetään vahvaa roolia (7) asiakkaan osallistamisessa yhteistyöhön. Tällöin asiakaslähtöinen näkökulma olisi toiminnan perustana (22). Kuorilehdon (7) mukaan asiakkaan osallistaminen yhteistyöhön onkin nähty esteenä moniammatillisessa yhteistyössä, vaikka se toisaalta nähdään myös asiakaslähtöisyyden $(2,6,7)$ ja moniammatillisuuden $(7,30)$ toteutumisen yhtenä edellytyksenä.

Yhteiskunnassa on viime vuosina keskusteltu paljon asiakaslähtöisyydestä ja asiakkaiden aktiivisesta roolista itseään koskevien asioiden hoitamisessa. Tämän tutkimuksen perusteella edelleenkään vanhemmilla ei ole todellisuudessa mahdollisuutta osallistua asioidensa hoitamiseen sillä tasolla kuin asiakaslähtöisyyden toteutuminen edellyttäisi. Tämän tutkimuksen perusteella vanhempien osallisuutta verkostoyhteistyöhön tuleekin tarkastella kriittisesti sekä kehittää verkostoyhteistyötä ja sen koordinoimista siten, et- tä vanhemmat pääsisivät passiivisen läsnäolijan roolin sijasta aktiivisen toimijan rooliin.

Yhteiskunnallisessa keskustelussa korostetaan asiakkaan kokemusten ja osallisuuden huomioimista palveluiden kehittämisessä ja suunnittelussa (1). Myös sosiaali- ja terveydenhuollon oikeudellinen sääntely ohjaa asiakkaan huomioimiseen palveluprosessissa (2). Moniammatillisten verkostotapaamisten kehittäminen asiakaslähtöisemmiksi edellyttää näin ollen asiakkaan, tässä yhteydessä vanhemman, mukaan ottamista verkostoyhteistyöprosessin eri vaiheisiin. Tämä mahdollisesti lisäisi vanhemman vaikuttamismahdollisuuksia sekä kokemusta tasavertaisesta osallisuudesta ja toimijuudesta verkostoyhteistyössä. Asiakaslähtöisessä toimintatavassa asiakkaan tulisikin olla tasa-arvoinen kaikissa yhteistyöprosessin vaiheissa: hoitoa suunniteltaessa, kehitettäessä ja arvioitaessa (6).

Tämän tutkimuksen mukaan vanhemmat pitivät tärkeinä verkostotapaamisia ja arvostivat ammattilaisten taitoa hoitaa heidän asioitaan, joten verkostoyhteistyön kehittämiselle on vahva pohja. Moniammatillista verkostoyhteistyötä kehitettäessä korostuu johtamisen merkitys $(7,42)$. Moniammatillisen verkostoyhteistyön on tärkeää olla lasten ja perheiden hyväksi tehtävää koordinoitua ja tavoitteellista toimintaa, jossa on määritelty toiminnan päämäärät ja ammattilaisten vastuut lasten ja perheiden asioiden hoitamisessa. Asiakaslähtöisen moniammatillisen verkostoyhteistyön koordinoimiseen tarvitaan lapsi- ja perhepalveluiden johtajien vastuuta, kun luodaan, seurataan ja arvioidaan moniammatillisen yhteistyön toimintaperiaatteita (7). Nykypäivän ja tulevaisuuden suuntauksena ovat integroidut sosiaali- ja terveyspalvelut, joissa asiakas on keskiössä. Moniammatillinen verkostoyhteistyö on juuri oleellinen esimerkki integroidusta palvelusta, jossa yhdistyy inhimillisyys ja tehokkuus lasten ja perheiden hyväksi. Moniammatillisen verkostoyhteistyön kehittämisessä tarvitaan hallintoalojen välistä vuoropuhelua sekä hallintoalojen johtajien yhteistyötä lapsi- ja perhepalveluiden toimintojen parantamiseksi.

\section{EETTISYYS JA LUOTETTAVUUS}

Tutkimuslupa pyydettiin kuntayhtymien johtavilta viranhaltijoilta. Tiedonantajia kohtaan oltiin herkkätunteisia ja ymmärtäväisiä sekä heidän 
yksityisyyttään kunnioitettiin. Tiedonantajille annettiin myös tutkijan yhteystiedot kirjallisena, jotta heillä oli mahdollisuus olla yhteydessä tutkijaan myös haastattelun jälkeen. Tutkimuksen tiedonantajien anonymiteetin säilymistä vahvistettiin suorien lainauksien muuttamisella kirjakielen muotoon.

Tämän tutkimuksen luotettavuutta arvioidaan laadullisen tutkimuksen luotettavuuden arvioinnin kriteereillä, joita ovat uskottavuus, siirrettävyys, riippuvuus ja vahvistettavuus (38) sekä aineiston rikkauden ja saturoitumisen perusteella (39). Tutkimuksen otos on pieni ja tuo esiin vain muutaman kunnan alueelta kerättyjen vanhempien kokemuksia. Tutkimuksen toteuttaminen laajemmalla alueella ja laajemmalle joukolle olisi voinut tuoda esiin laajempaa näkökulmaa ja lisätä siten tutkimuksen luotettavuutta. Tiedonantajien pyytäminen ilman lapsi- ja perhepalveluiden työntekijöiden osallistumista rekrytointiin olisi voinut myös lisätä tutkimuksen luotettavuutta, koska joidenkin tiedonantajien vastauksien antamiseen saattaa vaikuttaa se, että työntekijöillä on tieto tutkimukseen osallistumisesta.

Tulosten uskottavuutta lisää monipuolinen ja rikas aineisto. Haastatteluiden puolessa välissä aineisto alkoi myös saturoitumaan eli haastatteluista alkoi nousta samansisältöisiä vastauksia. Yksilöhaastattelut olivat ilmapiiriltään luottamuksellisia ja vapaita. Haastatteluissa tutkija pystyi tarkentamaan tiedonantajan kokemuksia lisäkysymyksillä. Tutkija pyrki olemaan vaikuttamatta tiedonantajien käsityksiin ja mielipiteisiin esittäessään tarkentavia kysymyksiä keskustelujen aikana.

Moniammatillisten verkostotapaamisten toiminta voi vaihdella eri organisaatioissa, joten tämän tutkimuksen tulokset eivät ole suoraan siirrettävissä toisiin organisaatioihin. Kuitenkin siirrettävyyttä on pyritty lisäämään tutkimusprosessin tarkalla kuvaamisella, jolloin tutkimus voidaan toteuttaa samanlaisena toisessa organisaatiossa. Vahvistettavuutta on tuettu suorien lainauksien käyttämisellä sekä tulosten tarkastelulla aikaisempaan tutkimustietoon $(29,26)$. Suorien lainausten käyttämisellä lukijalle voidaan mahdollistaa tulosten tarkastelu suhteessa aineistosta tehtyihin tulkintoihin.

Aineiston analysointiin osallistui kolme tutkijaa, joista yhden rooli oli aineiston analysoinnin toteuttaminen kokonaisuudessaan ja kahden muun tutkijan rooli oli analyysiprosessin etenemisen arviointi ja kommentointi. Kolmen tutkijan osallistumisella voitiin varmistaa aineiston analyysin toteuttaminen luotettavasti (26.) Analyysin toteuttavan tutkijan ammatillinen positio lapsi- ja perhepalveluissa oli etuna aineiston sisällöllisessä ymmärtämisessä. Ammatillisen position vuoksi tutkijan täytyi kuitenkin pitäytyä tiukasti aineiston objektiivisessa tarkastelussa sekä haastatteluiden toteuttamisessa ja aineiston analyysissa keskittyä tutkimustehtävää vastaaviin asioihin. Täydellisen objektiivisuuden saavuttaminen on kuitenkin aina haaste laadullisessa tutkimuksessa (29). Sen vuoksi tutkimuksen tulosten esittämisessä käytettiin paljon suoria lainauksia aineistosta, jotta voidaan todentaa lukijalle tulosten perustuminen alkuperäiseen aineistoon.

\section{PÄ̈̈TELMÄT JA JATKOTUTKIMUSAIHEET}

Lapsi- ja perhepalveluiden moniammatillinen verkostoyhteistyö oli vanhemmille oleellinen toimintamalli lapsen ja perheen asioiden hoitamisessa, minkä vuoksi moniammatillisen verkostoyhteistyön juurruttaminen lapsi- ja perhepalveluiden toimintaan on keskeinen kehittämiskohde. Moniammatillista verkostoyhteistyötä kehitettäessä on tärkeää tiedostaa haasteet vanhemman osallistamisessa verkostoyhteistyöhön sekä verkostoyhteistyön suunnittelussa, tiedonkulussa ja ammattilaisten yhteistyöosaamisen toteutumisessa sekä lääkäreiden oikeutettuun valtaan liittyvä perinteinen toimintakulttuuri suhteessa tulevaisuuden suuntaukseen sosiaali- ja terveyspalveluiden integraatiosta. Vaikuttavan ja toimivan moniammatillisen verkostoyhteistyön onnistumiseksi tarvitaan hallinnonalojen johtajien ja moniammatillisen verkostoyhteistyön ammattilaisten ja asiakkaiden välistä vuoropuhelua. Ammattilaisten vastuiden määritteleminen asiakkaiden asioiden hoitamisessa, ammattilaisten sitoutuminen verkostoyhteistyön yhteisiin pelisääntöihin ja yhteisen päämäärän tavoitteellisuuteen tulisi olla moniammatillisen verkostoyhteistyön kehittämisen lähtökohta, jotta toiminta olisi vaikuttavaa asiakkaan hyväksi. Moniammatillisen verkostoyhteistyön kehittäminen edellyttää kuitenkin selkeää koordinointia. Lapsi- ja perhepalveluiden johtajien rooli moniammatillisen verkostoyhteistyön ja verkostoyhteistyöprosessien koordinoimisessa ja kehittämisessä sekä toimintaperiaatteiden luo- 
misessa olisi tärkeä nähdä asiakaslähtöisen moniammatillisen verkostoyhteistyön kehittämisen perustana. Sosiaali- ja terveydenhuollon johtajille tutkimus antaa aihetta nostaa organisaatioiden asiakaslähtöisyyden näkökulmaa yhä enemmän toimintojen kehittämisen perustaksi sekä eri ammattilaisten yhteistyön kehittämisen lähtökohdaksi.

Tutkimuksen tulosten perusteella todetaan, että

- lapsi- ja perhepalveluiden moniammatillisen verkostoyhteistyön asiakaslähtöisyyttä on mahdollista kehittää koordinoimalla verkostoyhteistyöprosessin eri vaiheita paremmin asiakkaiden tarpeita vastaavaksi.

- moniammatillisen verkostoyhteistyön kehittämisen koordinoimisen vastuu lähtee lapsija perhepalveluiden johtajista, joiden tulee huomioida verkostoyhteistyön resurssointi, jotta ammattilaisilla on mahdollisuus suunnitella ja toteuttaa sitä riittävän hyvin.

- yli hallintorajojen toimivien ja verkostoyhteistyöhön osallistuvien ammattilaisten verkostoyhteistyökykyyn on tärkeää kiinnittää huo- miota. Esimerkiksi lääkärien ymmärrys moniammatillisesta verkostoyhteistyöstä ja asiakaslähtöisyydestä saattaa olla heikkoa. Osaamista ja ymmärrystä voidaan kehittää lisäkoulutuksella.

- tieteellisessä tutkimuksessa otetaan huomioon tarve asiakkaan näkökulman esiin tuomiselle. Jotta lapsi- ja perhepalveluiden moniammatillista verkostoyhteistyötä asiakaslähtöisyyden näkökulmasta voidaan kehittää tutkittuun tietoon perustuen, tarvitaan aiheesta lisää tutkimusta.

\section{RAHOITTAJAT:}

Tutkimusta ei ole rahoittanut mikään taho.

\section{KIRJOITTAJIEN KONTRIBUUTIOT:}

Laitila toteutti tutkimuksen suunnittelun, aineiston keruun ja aineiston analysoinnin sekä kirjoitti käsikirjoituksen. Lunkka ohjasi ja kommentoi tutkimussuunnitelmaa sekä osallistui käsikirjoituksen kirjoittamiseen ja Suhonen osallistui käsikirjoituksen kommentointiin.

\section{Laitila, H., Lunkka, N., Suhonen, M. Customer orientation in multiprofessional network collaboration within child and family services: Parents' experiences of the network meetings. Sosiaalilääketieteellinen aikakauslehti - Journal of Social Medicine 2020: 57: 3-I6.}

The purpose of the study was to describe parents' experiences of multiprofessional network collaboration from the perspective of customer orientation within child and family services. The informants in the study were ten $(\mathrm{n}=10)$ parents who had taken part in multiprofessional network meetings within municipal and specialised health care child and family services in one Finnish province. The material was collected with an open interview and analysed with content analysis.

The study demonstrated that at its best, network collaboration within child and family services supports parents and creates a strong basis for a good customer relationship. The elements of the network process and the involvement of the parents in the network collaboration process were seen as the basis of the implementation of customer orientation. The study also brought up challenges that hinder the realisation of customer orientation. Lack of planning and evaluation of the network collaboration process together with the parent as well as lack of sufficient dissemination of information and parents`involvement in the network collaboration were themes that emerged as parents' experiences of the network meetings. The study provides new information that can be utilised in developing multiprofessional network collaboration. The study also provides valuable information for the coordination and development of multiprofessional network collaboration.

Keywords: customer orientation, multiprofessionalism, network collaboration, child and family services

$$
\begin{array}{cc}
\text { Saapunut } & 12.10 .2018 \\
\text { Hyväksytty } & 08.05 .2019
\end{array}
$$


1. Sosiaali- ja terveysministeriö STM. www.sivut. http://stm.fi/hankkeet/lapsi-ja-perhepalvelut. Luettu 1.3.2018. 2018.

2. Virtanen P, Suoheimo M, Lamminmäki S, Ahonen P \&Suokas M. Matkaopas asiakaslähtöisten sosiaali- ja terveyspalveluiden kehittämiseen. Tekesin katsaus 281/2011. Helsinki; 2011.

3. Rod M \& Ashill N. The impact of hospital customer orientation on burnout of public hospital service workers in New Zealand. Journal of Strategic Marketing 2015; 23(3): 189-208. https://doi.org/10.1080/0965254X.2014.914074

4. Laitila M. Asiakkaan osallisuus mielenterveys- ja päihdetyössä. Fenomenografinen lähestymistapa. Väitöskirja. Itä-Suomen yliopisto, terveystieteiden laitos. 2010.

5. Koivunen, K. Asiakas- tai ihmislähtöisyys - tasavertaisuutta ja vastavuoroisuutta ammattilaisten ja palvelun käyttäjien kanssa. ePooki. Oulun ammattikorkeakoulun tutkimus- ja kehitystyön julkaisut 6 . http://urn.fi/urn:isbn:978-951-597-141-8. Luettu 1.3.2018. 2017.

6. de Silva, D. Helping measure person-centred care. London: The Health Foundation. 2014.

7. Kuorilehto R. Moniasiantuntijuus sosiaali- ja terveydenhuollon perhetyössä. Monitahoarviointi Q-metodologialla. Väitöskirja. Oulu. Oulun yliopisto, Lääketieteellinen tiedekunta, Terveystieteiden laitos. 2014.

8. Tsai Y. Health care industry, customer orientation and organizational innovation: a survey of Chinese hospital professionals. Chinese Management Studies 2013; 7(2): 2-16. https://doi.org/10.1108/CMS-Oct-2011-0086

9. Karlsson M, Garvare R, Zingmark K \& Nordstöm B. Customer orientation in a Swedish county council. International Journal of Quality and Service Sciences 2016; 8(1): 2-16. https://doi.org/10.1108/IJQSS-06-2015-0053

10. Ludwiczac A. Customer requirements and the quality improvement of health vare services. Management 2016; 20(2): 428-441. https://doi.org/10.1515/manment-2015-0073

11. Trybou J\& Gemmel P. Fulfilment of administrative and professional organisational obligations and nurses' customer-oriented behaviors. Journal of Nursing Management 2016; 24: 605-613. https://doi.org/10.1111/jonm.12363

12. Bruno A, Dell Aversena G \& Zunino A. Customer orientation and leadership in the health service sector: the role of workplace social support. Frontiers in Psychology 2017; 8. https://doi.org/10.3389/fpsyg.2017.01920

13. Ogougha M. Promoting patientcentered care through staff development. Nursing Standard 2013; 27(34): 42-46. DOI: $10.7748 / \mathrm{ns} 2013.04 .27 .34 .42 . e 6191$

14. Gountas S \& Gountas J. How the warped relationships between nurses`emotions, attitudes, social support and perceived organizational conditions impact customer orientation? The Journal of Advanced Nursing 2016; 72(2): 283-293. https://doi.org/10.1111/jan.12833

15. Gountas S, Gountas J, Soutar G \& Mavondo F. Delivering good service: personal resources, job satisfaction and nurses "customer'(patient) orientation. The Journal of Advanced Nursing 2014; 70(7): 1553-1563. https://doi.org/10.1111/jan.12308

16. Bogyun $\mathrm{K} \&$ Jia L. Relationships between personal traits, emotional intelligence, internal marketing, service management and customer orientation in Korean outpatient department nurses. Asian Nursing Research 2016; 10(1): 18-24. https://doi.org/10.1016/j.anr.2015.10.005

17. Kuusela M, Hupli M, Johansson K, Routasalo P \& Eloranta S. Moniammatillinen osaaminen iäkkään kotihoidon asiakkaan fyysisen toimintakyvyn tukemisessa; Hoitotiede 2010:22(2) (96-107).

18. Hyvönen S. Moniulotteista ja moniammatillista yhteistyötä muutosten keskellä. Tutkimus perusterveydenhuollon mielenterveystyöstä. Väitöskirja. Tampere. Tampereen yliopisto, hoitotieteen laitos. 2004.

19. Eloranta S \& Kuusela M. Moniammatillinen yhteistyö -katsaus suomalaisiin opinnäytetöihin. Tutkiva hoitotyö 2011; 9(3): 4-13.

20. Petri L (2010) Concept analysis of Interdisciplinary Collaboration. Nursing Forum 2010:45(2) (73-82). https://doi.org/10.1111/j.1744-6198.2010.00167.x

21. Kassianos A.P, Ignatowicz A, Greenfield G, Majeed A, Car J \& Pappas Y. "Partners rather than just providers...": A qualitative study on health care professionals' views on implementation of multidisciplinary group meetings in the North West London Integrated Care Pilot. International Journal of Integrated Care 2015; 15: 1-15. http://doi.org/10.5334/ijic.2019

22. Rautio S. Kumppanuus ja moniammatillinen yhteistyö neuvolan perhetyössä. Sosiaalilääketieteellinen aikakauslehti 2014:51 (191-202).

23. D’Amour D \& Oandansan I. Interprofessionality as the field of interprofessional practice and interprofessional education: An emerging concept. Journal of Interprofessional Care 2005:19(1) (8-20). https://doi.org/10.1080/13561820500081604

24. Kyngäs H, Elo S, Pölkki T, Kääriäinen M \& Kanste O. Sisällön analyysi suomalaisessa hoitotieteellisessä tutkimuksessa. Hoitotiede 2011:23(2) (138-148).

25. Eriksson P \& Kovalainen A. Methods in business research. Sage publications Ltd. London. DOI: http://dx.doi.org/10.4135/9780857028044. Luettu 1.3.2018. 2008.

26. Elo $S \&$ Kyngäs $H$. The qualitative content analysis process. Journal of Advanced Nursing 2008; 62(1), 107-115 doi: 10.1111/j.1365-2648.2007.04569.x 
27. Kylmä J \& Juvakka T. Laadullinen terveystutkimus. Edita Prima Oy. Helsinki; 2007.

28. Schreier M. Qualitative content analysis. Teoksessa Flick U (toim.) The SAGE handbook of qualitative data analysis. SAGE publications Ltd. London; 2014.

29. Graneheim UH \& Lundman B. Qualitative content analysis in nursing research: concepts, procedures and measures to achieve trustworthiness. Nurse Education Today 2004; 24(2): 105-112. https://doi.org/10.1016/j.nedt.2003.10.001

30. Isoherranen K. Uhka vai mahdollisuus - moniammatillista yhteistyötä kehittämässä. Väitöskirja. Helsinki. Helsingin yliopisto, sosiaalitieteiden laitos. 2012.

31. Pärnä K. Kehittävä moniammatillinen yhteistyö prosessina. Lapsiperheiden varhaisen tukemisen mahdollisuudet. Väitöskirja. Turku. Turun yliopisto, yhteiskuntatieteellinen tiedekunta. 2012.

32. Atwal A \& Caldwell K. Nurses perceptions of multidisciplinary team work in acute healthcare. International Journal of Nursing Practice 2006:12(6) (359-365).

https://doi.org/10.1111/j.1440172X.2006.00595.x

33. Xyrichis A \& Lowton K. What fosters or prevents interprofessional teamworking in primary and community care? A literature review. International Journal of Nursing Studies 2008:45(1) (140-153). https://doi.org/10.1016/j.ijnurstu.2007.01.015

34. Choi B. C.K \& Pak A. W.P. Multidisciplinarity, interdisciplinarity and transdisciplinarity in health research, services, education and policy: 1. Definitions, objectives and evidence of effectiveness. Clinical \& Investigative Medicine 2006:29(6) (351-364).

35. Aro J. Verkosto yhteiskuntatieteellisenä metaforana. Tiede ja edistys 1998: 23(3):186- 197. http://elektra.helsinki.fi.pc124152.oulu.fi:8080/ se/t/03563677/23/3/verkosto.pdf. Luettu 2.3.2018. 1998.

36. Järvensivu T, Nykänen K \& Rajala R. Verkostojohtamisen opas. Verkostotyöskentely sosiaalija terveysalalla. Muutosvoimaa vanhustyön osaamiseen -hankkeen osajulkaisu. Aaltoyliopiston kauppakorkeakoulu. 2010.

37. Määttä M. Yhteinen verkosto? Tutkimus nuorten syrjäytymistä ehkäisevistä poikkihallinnollisista ryhmistä. Väitöskirja. Helsingin yliopisto. Helsinki; 2007.

38. Lincoln YS \& Guba EG. Naturalistic inquiry. Sage publications. California; 1985.

39. Elo S, Kääriäinen M, Kanste O, Pölkki T, Utriainen K \& Kyngäs H. Qualitative Content Analysis: A Focus of Trustworthiness. SAGE Open. 2014; 4.

https://doi.org/10.1177/2158244014522633

40. Tutkimuseettinen neuvottelukunta (TENK) wwwsivut. Eettinen ennakkoarviointi ihmistieteissä. http://www.tenk.fi/fi/eettinen-ennakkoarviointiihmistieteissa. Luettu 2.3.2018.
41. Korkala S. Luottamuksen ilmeneminen alueellisissa yhteistyöverkostoissa. Turun yliopiston julkaisuja. Turun yliopisto. Turku; 2010.

42. Van Dijk-deVries A., Van Dongen JJJ \& Van Bokhoven MA. Sustainable interprofessional teamwork needs a team-friendly healthcare system: Experiences from a collaborative Dutch programme. Journal of interprofessional care 2017:31 (2) (167-169).

https://doi.org/10.1080/13561820.2016.1237481

43. Timonen-Kallio E. Interprofessional collaboration between residential child care and mental care practitioners: a cross-country study in six European countries. European journal of social work 2018:7 (1-14). https://doi.org/10.1080/13691457.2018.1441135

44. Tiirinki H. Näkyvien ja piilotettujen merkitysten rajapinnoilla - Terveyskeskukseen liittyvät kulttuurimallit asiakkaan näkökulmasta. Väitöskirja. Oulun yliopisto. Oulu; 2014.

45. Holmesland AL., Seikkula J., Nilsen Ö., Hopfenbeck M \& Arnkil TE. Open dialogues in social network: professional identity and transdisciplinary collaboration. International journal of integrated care 2010:10.

46. van der Eijk M., Bloem B., Nijhuis Frouke AP., Koetsenruijter J., Vrijhoef Hubertus JM., Munneke M., Wensing M \& Faber M. Multidisciplinary collaboration in professional networks for PD. A Mixed-Method Analysis. Journal of parkinson's disease 2015:5 (4) (937-945). DOI: $10.3233 /$ JPD-150673

47. Lannon CM \& Peterson LE. Pediatric collaborative networks for quality improvement and research. Academic pediatrics 2013:13 (6) (S69-S74). https://doi.org/10.1016/j.acap.2013.07.004

\section{Heidi Laitila}

TtM, Osastonhoitaja

Oulun yliopisto

Hoitotieteen ja terveyshallintotieteen tutkimusyksikkö

\section{NinA LUNKKA \\ TtT, Tutkijatobtori \\ Oulun yliopiston kauppakorkeakoulu \\ Markkinoinnin, johtamisen ja kansainvälisen liketoiminnan laitos}

\author{
Marjo SuHonen \\ TtT, Dosentti, Yliopiston lehtori \\ Oulun yliopisto, hoitotieteen ja \\ terveyshallintotieteen tutkimusyksikkö. Medical \\ Research Center,Oulu \\ Hoitotieteen ja terveyshallintotieteen \\ tutkimusyksikkö
}

